\title{
Erratum: Navigating comics: an empirical and theoretical approach to strategies of reading comic page layouts
}

\section{Neil Cohn*}

Center for Research in Language, University of California San Diego, La Jolla, CA, USA

*Correspondence: neilcohn@emaki.net

\section{Edited by:}

Eddy J. Davelaar, Birkbeck College, UK

Keywords: comics, page layout, spatial representation, reading order, writing systems

\section{An erratum on}

Navigating comics: an empirical and theoretical approach to strategies of reading comic page layouts

by Cohn N. (2013). Front. Psychol. 4:186. doi: 10.3389/fpsyg.2013.00186

This General Commentary provides a corrected version of the caption for Figure 2. The text should read:

(A) Canonical grid layout stereotypically read in a "Zpath." (B) Layout where a vertical panel "blocks" the creation of a row of panels. (C) Layout where panels are separated by a wide space. (D) Layout where panels overlap each other. (E) Layout where panels are staggered to no longer retain a contiguous gutter.

In addition, the link to the supplementary analysis of the Steranko page has been changed to: http://www.visuallanguage lab.com/P/ECS_Supplement.pdf

Received: 19 December 2013; accepted: 07 January 2014; published online: 24 January 2014.
Citation: Cohn N (2014) Erratum: Navigating comics: an empirical and theoretical approach to strategies of reading comic page layouts. Front. Psychol. 5:15. doi: 10.3389/fpsyg.2014.00015

This article was submitted to Cognitive Science, a section of the journal Frontiers in Psychology.

Copyright $(\odot 2014$ Cohn. This is an open-access article distributed under the terms of the Creative Commons Attribution License (CC BY). The use, distribution or reproduction in other forums is permitted, provided the original author(s) or licensor are credited and that the original publication in this journal is cited, in accordance with accepted academic practice. No use, distribution or reproduction is permitted which does not comply with these terms. 